\title{
Role of Public Space in Achieving Social Sustainability in Cairo
}

\author{
Mennat-Allah El-Husseiny \\ Architecture Department, Faculty of Engineering, \\ Cairo University, Egypt \\ mennatallahelhusseiny@gmail.com
}

\begin{abstract}
Public space has been always regarded as a reflection of the social status of the community. Based on this assumption, the challenge for achieving a 'socially sustainable' community in Cairo is in need to be re-questioned in relation to the role of public space. Accordingly, the paper explores the role of publicspace in maintaining the social sustenance in the extreme ends of Cairo's social structure, first: the gated communities taking 'Beverly Hills' as a prototype, and second the informal areas taking 'AlZahraa' district a prototype.
\end{abstract}

Keywords: Social sustainability; Neoliberalism; Public spaces; Gated communities.

eISSN 2398-4295 @ 2018. The Authors. Published for AMER ABRA cE-Bs by e-International Publishing House, Ltd., UK. This is an open-access article under the CC BY-NC-ND license (http://creativecommons.org/licenses/bync-nd/4.0/). Peer-review under responsibility of AMER (Association of Malaysian Environment-Behaviour Researchers), ABRA (Association of Behavioural Researchers on Asians) and cE-Bs (Centre for EnvironmentBehaviour Studies), Faculty of Architecture, Planning \& Surveying, Universiti Teknologi MARA, Malaysia.

DOI: x.doi.org/10.21834/ajbes.v3i9.72 


\subsection{Introduction}

Public space has been always regarded as a reflection of the social status of the community. Based on this assumption, the challenge for achieving a 'socially sustainable' community in Cairo; whose social capital is affected by the neoliberal market imperatives, is strategically in need to be re-questioned in relation to the role of public space. This is relevant in the shadows of the socio-political transformations taking place in the highly complicated Cairene society. Thus, the paper explores the role of public-space in maintaining social sustenance in the two extreme ends of Cairo's social structure, first: the gated communities at the desert plateaus surrounding Cairo, and second the informal areas, which represent the individual solutions by a great mass of Egyptian residents as a result of the deteriorated services during the past decades.

\subsection{Methodology}

The methodology adopted will be based on literature review of the related concepts of social sustainability and the relevant meaning of a sustainable community to the Cairene context. Then the development of public space in Cairo from a socio-political perspective is presented with its relation to the community structure up till the $25^{\text {th }}$ of January revolution. Finally, a field survey is implemented on the selected cases; Beverly Hills as a prototype of gated communities and Al-Zahraa, as an example of an informal housing district. This study will help in understanding the nature of social sustainability according to each locality, which will add another layer of understanding the socio-cultural role of public spaces in postrevolutionary Cairo.

\subsection{Defining 'Social Sustainability' and 'Sustainable Communities': Relevance to Cairo}

In order to be able to analyze the role of public space in maintaining social sustainability in Cairo, we first need to unveil what is meant by 'social sustainability', particularly as applied to the Cairene case. Accordingly, this part will explore the literature review of the definitions of 'social sustainability' and the 'sustainable community', followed by the interpreted measures relevant to Cairo to be used in the analysis.

It is first important to explain the inter-relation between public space and social sustainability. As Harvey (1996) presents, places are constructed as material ecological artefacts and intricate networks of social relations. They are the focus of the imaginary, of beliefs, longings and desires. In addition to this, Knox (2011) argues that the sense of place is always socially constructed. People generate meanings about buildings and spaces through routinized behaviours. Often this carries over into a collective and self-conscious 'structure of feeling', including the 'affective' dimension of feeling evoked as a result of the experiences that people 
associate with a particular place.

The definitions of social sustainability have been widely discussed among theorists and planners. According to Chan and Lee (2008), social sustainability refers to maintenance and improvement of well-being of current and future generations (Chiu, 2003). While Colantino et al (2009) presents social sustainability as blending traditional social policy principles, such as equity, with emerging issues concerning participation, needs, social capital, the economy, the environment, with the notions of happiness and quality of life. As to Sachs (1999: 27) a social sustainability must rest on the basic values of equity and democracy.

Chiu (2003) identifies three main approaches to the interpretation of social sustainability. The first interpretation equates social sustainability to environmental sustainability. The second interpretation, which she labels 'environment-oriented', refers to the social preconditions required to achieve environmental sustainability. Lastly, the third 'people-oriented', interpretation refers to improving the well-being of people and the equitable distribution of resources whilst reducing social exclusions.

More importantly, determining social sustainability in a certain community will aid in the field of this paper. Tsenkova (2009) argues that a sustainable community is one of shared interests such as cultural heritage, and one of locality, which is the residential area where people live. First, 'community' is a social term. It means a network of people with common interests. Moreover, it is an aggregate of characteristics including economic security and growth, environmental quality and integrity, social cohesion and quality of life, empowerment and governance.

As to Dempsey (2008), 'sustainable communities' are described as providing a 'safe and healthy environment with well-designed public and green space' with a 'sense of place'. In a more comprehensive approach, Ageyman (2005) presents that a 'Sustainable Community' is one which combines the three dimensions of the environment, the social needs and the economy.

Based on the above review, it can be deduced that there are five main doctrines which are relevant to the Cairene society that guide the evaluation of a local community whether to be socially sustainable or not. These five doctrines are the social capital, the environment, economy, political influences, and finally placemaking. Certainly, the relevant weight of each doctrine varies from one specific community to the other, thus, this is a quantitative not a qualitative approach.

These five aspects can be used as will be presented in the case studies to provide the points of strength and weakness in each local community, and provide guidelines for the deficiencies if found in a certain broad issue which can be used to enhance social sustenance. For instance, in informal sectors of Cairo, we can find very poor environmental conditions, yet, on the other side, strong social capital and local economy. On the contrary, in elite housing communities, we can find much 
emphasis on the environmental conditions and on the design of public spaces, yet devoid of liveability and social cohesion. Thus, the next part will provide a brief about the development of public spaces in Cairo as a reflection to the economic and political status up till neoliberal Cairo and the $25^{\text {th }}$ of January revolution to understand the current situation of social sustenance which will be further explored in the case studies.

\subsection{Development of Public-Space in Cairo: Socio-political Implications on the Social Structure}

The point of transformation for the Cairene public space from the traditional fabric was the end of the nineteenth century, when Khedive Ismail conceived a new city centre for Cairo. He dreamt of a Haussmanian Paris of boulevards uniting public squares and apartment blocks. Thus, the traditional city was altered into the westernized model in the new downtown which was associated to colonialism.

After the 1952 revolution, the new spaces produced reflected the nationalist aspirations of the government. The ambitions of the new rulers was modernizing the country and abolishing the class differences. At that time, modernizing the country was seen as synonymous to industrializing it so that Egypt could equal the West on its own terms. The establishment of these industries and their corollaries of massive housing projects for the newly-arrived migrants who constituted most of the labour transformed the landscape of Cairo to a great extent (Adham, 2004).

Following that, Sadaat' open-door policies, 'Infitah', were the initialization point of neoliberal market imperatives that transformed the typology and forms of public space within Cairo. The introduction of capitalism, the inflation and the westernized model adopted afterwards by Mubarak's regime initiated the privatization and socialsegregation within the city's public space.

Cairo became a city which is torn into two halves, the 1 st is embodied by the rise of all types of informal housing which increased by the effect of economic reform plans on the local currency. This as Adham (2005) explains has brought decline in the average family's purchasing power, which affected the housing markets. Lack of adequate, affordable housing forced many young families to seek alternative living space: in graveyards, garages, staircase vaults, and rooftop shacks (Adham, 2005).

The second half as exposed by Denis (2006) was the new developments on the desert plateaus bordering the city to the east and to the west. Dozens of luxury gated communities have burgeoned along the beltways. This new dimension of Cairo is marked by a flight of the urban elites from the urban centre. Despite their apparently diverse appearance, from an urban point of view there are important similarities between these emerging spaces of consumption. Whether a mall, a gated 
community, or some other development type, they all provide a carefully controlled environment that is physically, economically and socially isolated from surrounding. Finally, they enforce codes of behaviour to uphold the utopian imagery which gives them their economic and symbolic value, see Fig. 1.

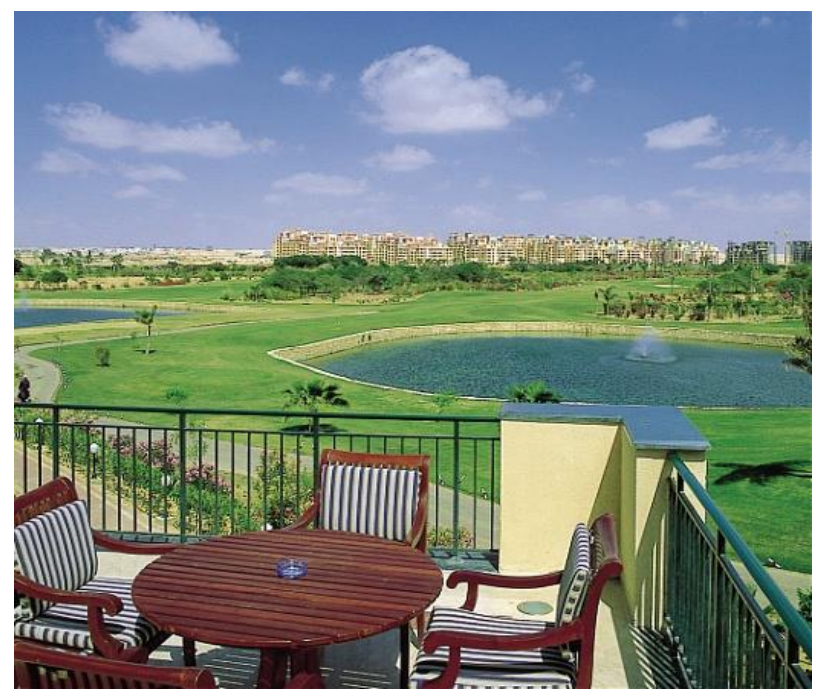

Fig. 1. View from an apartment at Dreamland in $6^{\text {th }}$ of October, Dreamland website, 2012

During the last decade of Mubarak's ruling era, the social and economic conditions in Egypt deteriorated to an unprecedented extent. The gap between the two ends of the community widened. The deteriorated conditions led to frustration among the Egyptian people. Accordingly, the revolution started, and the target was first and foremost the reclaim of public space and the calls for freedom, social justice and the right to a dignified life.

Those stated motives were justified in the 'occupation' of one of the most strategic squares in Cairo, Al-Tahrir Square, for which every party was aiming to declare its right for being. The angry crowds did not mind the violence of the regime, and succeeded to a great extent during the 18 days to transform the re-claimed public space into a real socially sustainable public space of encounter. This was relevant according to the five previously discussed doctrines through the establishment of a strong social capital where shared interests were the base and social cohesion between the poor and the middle income classes strongly appeared. The environmental aspects were apparent in the urge of people to maintain the wellbeing and cleanliness of the square even amid the battles. The economy played an 
important role in presenting the ability of the people to self-sustain their beings through local economy. As to the policy and governance, the different political ideologies were all unified to face the corrupted regime; accordingly, acceptance and empowerment were present among all parties. Finally, as to place-making, the activities, the memorials and the social and artistic events taking place, all developed a strong image of the square or 'al midan', see Fig. 2.

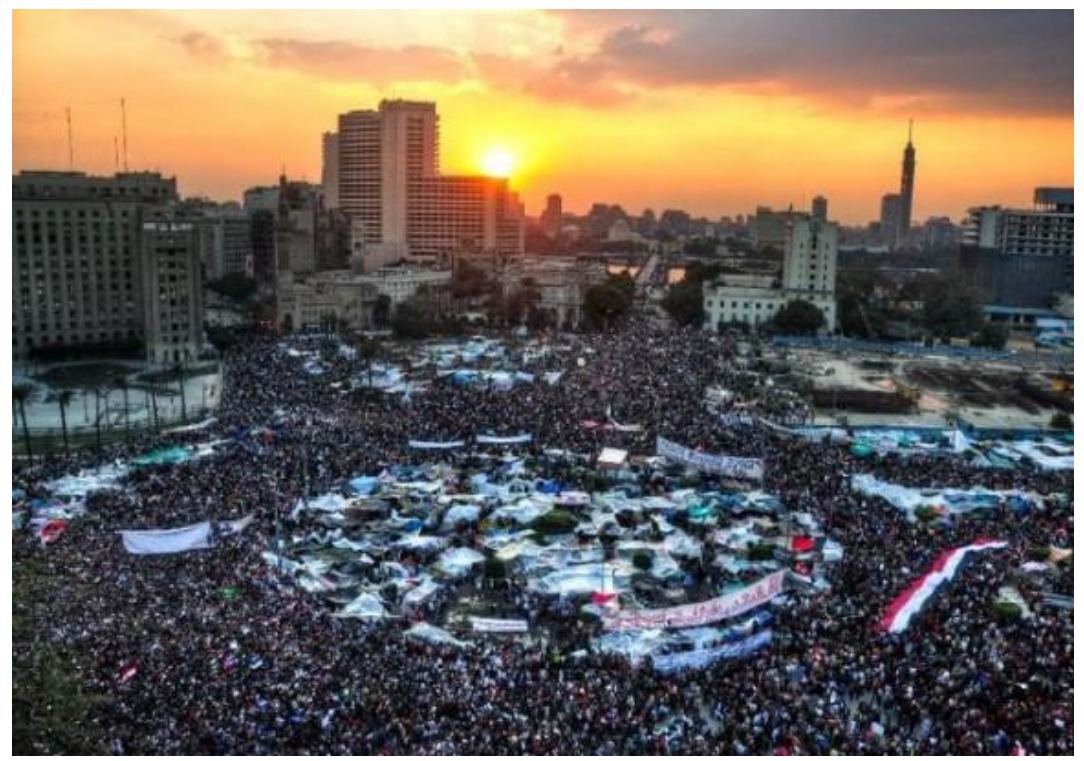

Fig. 2. Tahrir Square during the early days of the revolution, Al-Ahram Newspaper, 2011

\subsection{Analysis of the role of public-space in maintaining social sustenance in Cairo}

\subsection{Beverly Hills: Public Space of Gated Communities:}

Beverly Hills was one of the first large compounds to be developed in Sheikh Zayed and represents a prototype of new housing communities which developed at the outskirts of Cairo, following the neoliberal paradigm during Mubarak's era.

The social capital in Beverly Hills is based on two groups of users, the residents of the units, who belong to the high middle or upper income classes, and escaped the city center due to deterioration, on the other side are the workers who occupy the serving jobs, who either come from other countries to work or residents of far districts who take the daily trip form and to the compound. The problem associated with this type of social cohesion among the residents who all belong to the same class, while at the same time social segregation of 
all other classes of the society is that the younger generations will never see the 'other' except as a serving person. This kind of problems will increase not decrease the social injustice which the revolution was standing against, see Fig. 3.

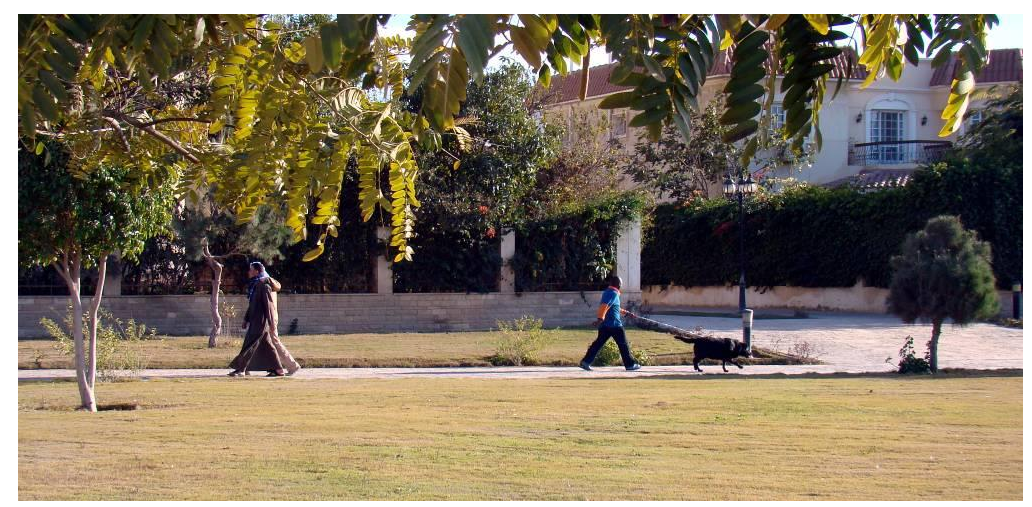

Fig. 3. The paradox between the user's of the public space in Beverly Hills, either elite residents or guards, Author, 2012.

There is a clear difference between the environmental quality between the new district and downtown, regarding the pollution of air and solid wastes. However, there are no attempts towards building a green, eco-friendly environment in terms of reducing $\mathrm{CO} 2$ transitions, reducing the use of water and fuel. Besides taking into consideration the fact that the residents work at distant places and the strong dependency on the private car leaves the whole environmental issue debatable.

The economic capital is partially local and mostly depending on megastores present at the $6^{\text {th }}$ of October city. The locally driven shops are used by the residents at a very limited scale. This is due to the increased price of the goods, which in turn are due to the long distances and the deficiency of stores. However, the presence of outing places, such as the clubhouse, although still limited but started to provide some sort of 'third places' in which the residents began to enjoy nightlife and social interaction, see Fig. 4 .

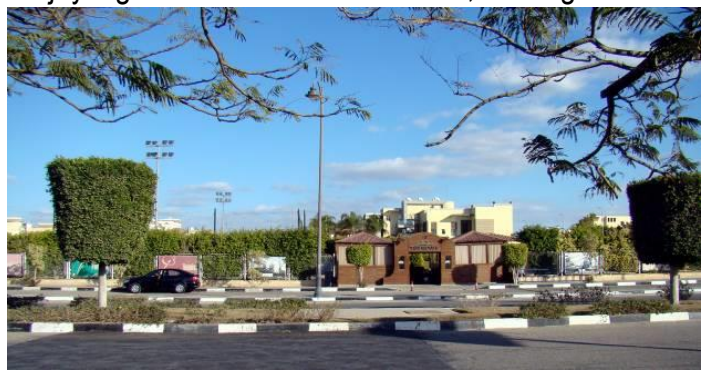

Fig. 4. Clubhouse at Beverly Hills with limited users, Author, 2012. 
As to the politics of public space in the compound, this aspect appeared to be very weak in the course of the study. The public spaces are used for leisure and as aesthetic places, but no calls were arranged even during the time of the revolution due the sole role of the district which is the residence.

Finally, the issue of place-making is very controversial in Beverly Hills like the other gated communities in Cairo. The public spaces are well designed and maintained, due to the efforts of the owning company. However, the spaces host very few activities, which are to some extent individual as presented by the residents. The activities range from jogging, dogs' walk, playing of children, but in the absence of strong economic or cultural forces, these activities are very limited, see Fig. 5.

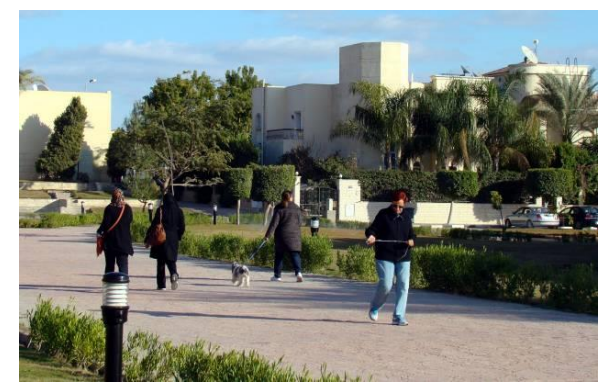

Fig. 5. Uses of open spaces at Beverly Hills, Author, 2012.

\subsection{Al-Zahraa: The Public Space in the 'Informal'}

Al-Zahraa district in old Cairo is a prototype of an informal settlement which emerged on the hilltop contours beside the ring-road surrounding Cairo see Fig. 6 . The district was built by the self-finance of the people, with no planning from the government.

The social capital is constructed from low-income groups and temporary workers; although there are still groups who ideologically belong to the middle income groups, however, suffer from high living expenses. The social bonds are definitely strong among the residents when facing 'outcomers', although there are sub-groups and lobbying among the residents themselves when inner problems occur. Accordingly, social cohesion is apparent due to the shared beliefs and circumstances of the people.

The environmental conditions appear extremely deteriorated with the lack of proper infra-structure. This affected the health of the whole district's residents, see Fig. 7. In addition to this, solid wastes provide a strong source of pollution with the absence of a system of garbage recycling.

The economic base of the whole district is weak, depending on temporary works. However, the open spaces provide an excellent accommodator to locally based economic 
activities, for instance the market, the exhibitions of the workshops, the coffee shops, all utilize any left-over space to accommodate any activity no matter how small, see Fig.8.

Finally, the place-making is achieved even if not planned, through the accommodation of all sorts of activities within all levels of public space. This is relevant from the small alley, to the left over space, which can be used for a wedding ceremony or a temporary market, see Fig. 9. Although not designed and not aesthetically maintained, yet, still preserves its livability through its user's continuous activities

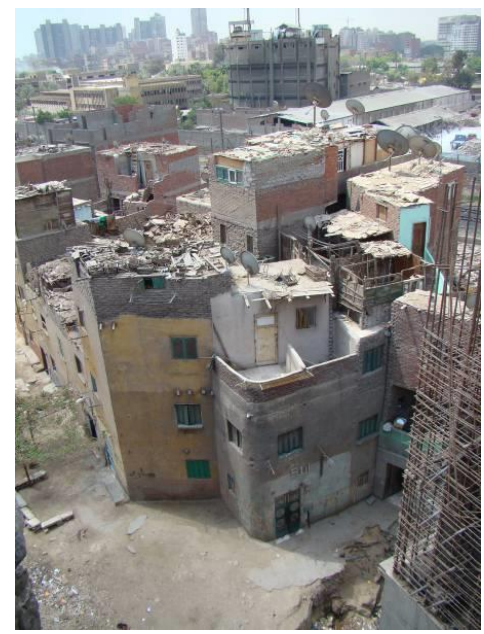

Fig. 6. Al-Zahraa informal housing district (Author, 2012)

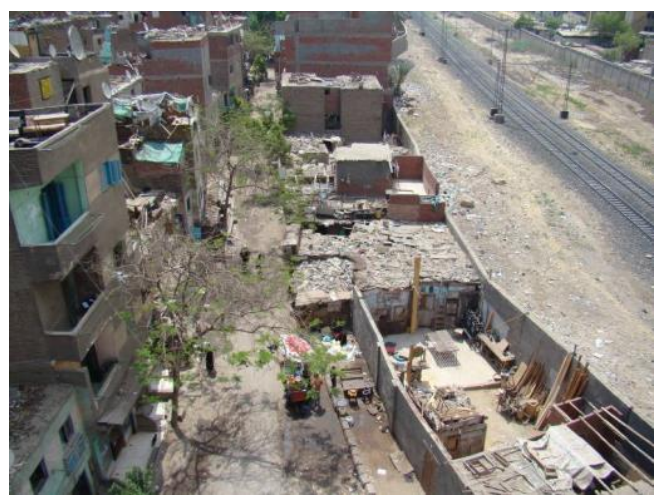

Fig. 7. Spread of garbage all over the district (Author, 2012) 


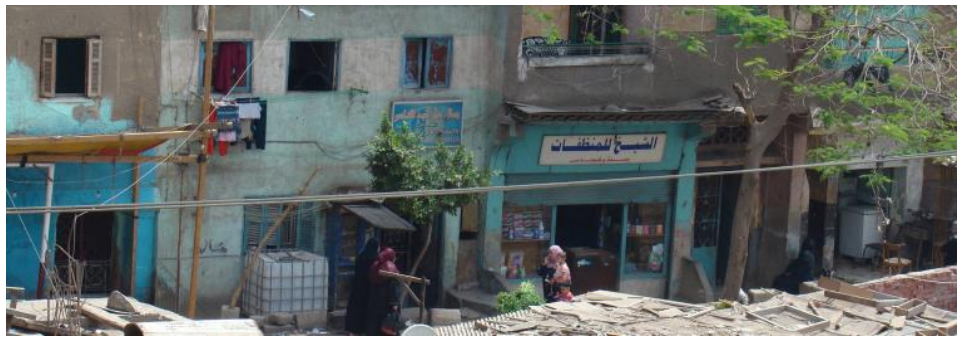

Fig. 8. The street used as an extension for shops and cafes (Author, 2012)

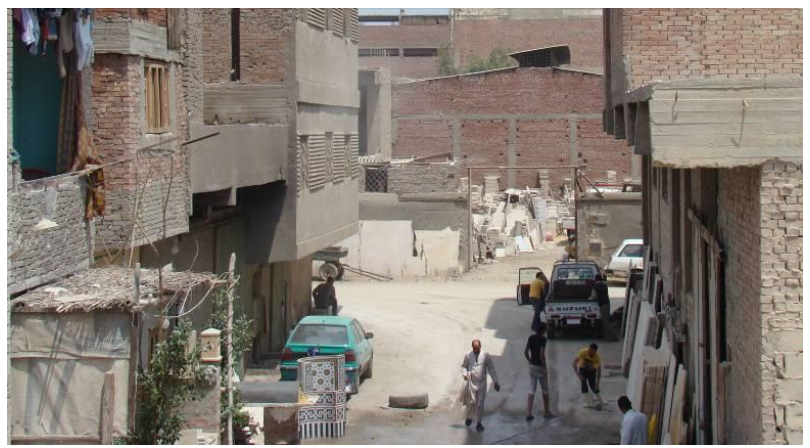

Fig. 9. Public space used as exhibition space

\subsection{Discussion}

(Author, 2012)

The analysis revealed the controversial lives of an example of the two extreme ends of Cairo's today social structure. The public space in the first case is used as a marketing tool, for the residents who have the right to move out of the crowded downtown and enjoy better living conditions. However, the issue of livability is hardly achieved, with the lack of real economic and cultural bases. Thus, a community in which the private home accommodates all possible leisure facilities and the outer space provide no new experiences turns into an introvert community that is closed although promised by more openness and freedom.

The 'other' end of the society which is currently being blamed for the lack of security, are the ones who actually fear the actions of the elite and educated. They rarely blame Mubarak's regime for their poor state, but always find ways to dwell and facilitate their conditions as much as they can afford. And since 'space' is all they have, they acquire the 
ability to add new experiences and plan for the best that accommodates their needs to the contrary of what most architects believe.

\subsection{Conclusion}

The paper explored the role of public space in achieving the social sustainability of a certain community through five main doctrines extracted from literature which are believed to be relevant to the Cairene case; the social capital, environmental conditions, economy, policy, and place making. As presented in the case study analysis, the public spaces of Beverly Hills were used occasionally due to the lack of diversity in the social capital and the lack of economic and political activities. On the contrary, the deteriorated environmental and physical conditions of the public space at Al-Zahraa did not stand against the achievement of livable economic and social places of encounter. Accordingly, the creation of public space is mostly the creation of the actual lively experiences, which is the dilemma of public spaces in neoliberal Cairo.

\section{References}

Adham, K. (2004). Cairo's Urban Déjà Vu : Globalization and Urban Fantacies. In Y. Elsheshtawy (Eds.), Planning Middle Eastern Cities, An Urban Kaleidoscope in a Globalizing World . Routledge.

Adham, K. (2005). Globalization, Neoliberalism, and New Spaces of Capital in Cairo, TDSR, 17:1.

Ageyman, J. (2005). Sustainable Communities and the Challenge of Environmental Justice, New York University Press.

Chan, E. and Lee, G. (2008). Critical factors for improving social sustainability of urban renewal projects, Soc Indic Res, 85: 243-256.

Chiu, R. (2003). Social sustainability, sustainable development and housing development: The experience of Hong Kong. In R. Forrest \& J. Lee (Eds.), Housing and social change: East-west perspectives (pp. 221-239). USA: Routledge.

Colantino, A. and Dixon, T. (2009). Measuring Socially Sustainable Urban Regeneration in Europe, Oxford Institute for Sustainable Development.

Dempsey, N. (2008). Does quality of the built environment affect social cohesion?, Proceedings of the Institution of Civil Engineers Urban Design and Planning, 161, pp.105-114.

Denis, E. (2006). Cairo as neoliberal capital?From Walled City to Gated Community, in D. Singerman and P. Amar (Eds), Cairo Cosmopolitan, AUC Press.

Harvey, D. (1996). Justice, Nature and the Geography of Difference. Blackwell Publishers.

Knox, P. (2011). Cities and Design. Routledge. 
El-Husseiny, M. / Asian Journal of Behavioural Studies (AjBeS), 3(9) Jan / Feb 2018 (p. 183-194)

Sachs, I. (1999), Social sustainability and whole development: exploring the dimensions of sustainable development. In: B. Egon and J. Thomas, (Eds.), Sustainability and the social sciences: a cross-disciplinary approach to integrating environmental considerations into theoretical reorientation, Zed Books.

Tsenkova, S. (2009). Planning Sustainable Communities Diversity of Approaches and Implementation Challenges, University of Calgary. 